\title{
Hubungan Fasilitas Kerja dengan Kepuasan Kerja di Unit Rekam Medis Rumah Sakit
}

\section{The Correlation between Work Facilities and Job Satisfaction at Hospital Medical Record Unit}

\author{
Nauri Anggita Temesvari ${ }^{1}$, Desmayanti Br Subakti ${ }^{2}$ \\ Fakultas Ilmu-ilmu Kesehatan, Universitas Esa Unggul, Indonesia
}

\section{ARTICLE INFO}

\section{Article history}

Received date

22 Apr 2020

Revised date

26 Apr 2020

Accepted date

11 August 2020

\section{Keywords:}

Hospital;

Human resources;

Job satisfaction;

Work facilities.

\section{Kata kunci:}

Rumah sakit;

Sumber daya manusia;

Kepuasan kerja;

Fasilitas kerja.

\author{
ABSTRACT/ ABSTRAK
}

Job satisfaction in hospitals was needed to improve the performance to be achieved by the hospital. Job satisfaction could have an impact on whether or not happy employees do their jobs. One factor that affects job satisfaction is work facilities. Job satisfaction in the PGI Cikini Hospital medical record unit looks not good. This could be seen from the absence of employees by $15 \%$. The problem complained by employees was the lack of work equipment provided by hospitals. The purpose of this study was to analyze the correlation between work facilities and job satisfaction at medical record unit PGI Cikini Hospital. This study used a cross-sectional study design with a total sample of all employees of the PGI Cikini Hospital Medical Record Unit with a total of 30 persons. The study was conducted from March to December 2019. The instrument used was a questionnaire. Analysis conducted descriptively to display the data of each variable and also analytically with Pearson correlation test to analyze the relationship between work facilities and job satisfaction. There was a strong, positive correlation between work facilities and job satisfaction ( $r x y=0,609)$. Work facilities and job satisfaction have a statistically significant linear relationship (p-value 0,000). There was a correlation between work facilities and job satisfaction at medical record unit PGI Cikini Hospital.
Kepuasan kerja karyawan di rumah sakit dibutuhkan untuk meningkatkan kinerja yang hendak dicapai oleh rumah sakit. Kepuasan kerja dapat berdampak pada senang atau tidaknya karyawan dalam melakukan pekerjaannya. Salah satu faktor yang mempengaruhi kepuasan kerja karyawan adalah fasilitas kerja. Kepuasan kerja karyawan di unit rekam medis RS PGI Cikini terlihat kurang baik. Hal ini dapat dilihat dari ketidakhadiran karyawan sebesar 15\%. Masalah yang dikeluhkan oleh karyawan adalah kurangnya peralatan kerja yang disediakan oleh rumah sakit.Tujuan penelitian ini adalah menganalisis hubungan fasilitas kerja dengan kepuasan kerja karyawan unit rekam medis RS PGI Cikini. Penelitian ini menggunakan desain studi potong lintang dengan jumlah sampel adalah seluruh karyawan unit rekam medis RS PGI Cikini yang berjumlah 30 orang. Penelitian dilakukan dari bulan Maret sampai dengan Desember 2019. Instrumen yang digunakan adalah kuesioner. Analisis yang dilakukan secara deskriptif untuk menampilkan data masing-masing variabel dan juga secara analitik dengan uji korelasi pearson untuk menganalisis hubungan antara fasilitas kerja dengan kepuasan kerja.Terdapat korelasi positif dan kuat antara fasilitas kerja dan kepuasan kerja dengan nilai $\mathrm{r}_{\mathrm{xy}} 0,609$. Fasilitas kerja juga memiliki hubungan yang signifikan dengan kepuasan kerja ( $p$-value 0,000). Secara statistik terdapat korelasi yang kuat antara fasilitas kerja dengan kepuasan kerja di unit rekam medis RS PGI Cikini.

Corresponding Author:

Nauri Anggita Temesvari

Fakultas Ilmu-ilmu Kesehatan, Universitas Esa Unggul, Indonesia

Email: nauri@esaunggul.ac.id

\section{PENDAHULUAN}

Rumah sakit adalah organisasi kesehatan yang menyelenggarakan dua jenis layanan kepada masyarakat, yaitu layanan kesehatan dan layanan administrasi. Kompetisi dalam industri rumah sakit saat ini menuntut organisasi untuk selalu memberikan layanan kesehatan yang 
terbaik kepada konsumen. Konsumen mencari produk dalam bentuk layanan kesehatan yang dapat memberikan kepuasan kepada mereka. Selain pelanggan setia, rumah sakit harus mencari dan mendatangkan pelanggan baru untuk pengembangan organisasi, tentunya juga mempertahankan pelanggan yang selalu loyal. Semua pelanggan ke fasilitas kesehatan tentu menginginkan layanan kesehatan yang baik dan berkualitas. Untuk mencapai tujuan ini, diperlukan dukungan dari kualitas peralatan medis dan sumber daya manusia (Prayoga, Lailiyah, \& Eka Sari, 2017). Sumber Daya Manusia merupakan salah satu sumber daya terpenting di rumah sakit, fungsi setiap sumber daya manusia tidak dapat digantikan oleh sumber daya lainnya. Sumber Daya Manusia saat ini tidak hanya dipandang sebagai beban, tetapi sebagai aset organisasi yang dapat meningkatkan kinerja organisasi (Kusumah, 2016).

Kepuasan kerja menjadi aspek penting yang harus diperhatikan karena dengan mengetahui tingkat kepuasan kerja karyawan, suatu organisasi dapat meningkatkan produktivitas dan efisiensi melalui peningkatan sikap dan perilaku karyawannya. Karyawan yang bekerja di suatu organisasi memiliki keinginan kuat untuk dapat memenuhi keinginan dan kebutuhannya di tempat dia bekerja. Kepuasan kerja tentu dapat diperoleh oleh karyawan jika ada kesamaan antara harapan dan kenyataan yang diperoleh di tempat kerja (Sulistyarini, 2013). Kepuasan kerja sangat penting bagi pekerja untuk tetap produktif dan bahagia. Pekerja yang produktif memberikan kinerja terbaik mereka (Thakur, 2020). Faktor-faktor yang mempengaruhi kepuasan kerja adalah kesempatan untuk maju, keamanan kerja, gaji, perusahaan dan manajemen, pengawasan, faktor intrinsik dan pekerjaan, kondisi kerja, aspek sosial, komunikasi, dan fasilitas kerja (Soetrisno, 2017).

Indikator untuk mengukur kepuasan kerja dapat dilihat dari pekerjaan itu sendiri, pengawasan, rekan kerja, promosi, dan gaji (Luthans, 2011). Uraian indikator adalah sebagai berikut:

1. Pekerjaan itu sendiri

Setiap pekerjaan membutuhkan keterampilan tertentu sesuai dengan bidangnya masing-masing. Sulit atau tidaknya suatu pekerjaan dan persepsi pekerja tentang pekerjaan, akan meningkatkan atau mengurangi kepuasan kerja.

\section{Pengawasan}

Seorang penyelia yang baik berarti mau menghargai pekerjaan karyawannya. Untuk karyawan, pengawas dapat dianggap sebagai orang tua dalam sosok keluarga serta pengawas.

3. Rekan kerja

Rekan kerja adalah bagian dari perusahaan yang terkait erat dengan selain penyelia.

4. Promosi

Promosi adalah faktor yang terkait dengan ada atau tidak adanya peluang untuk memperoleh peningkatan karier selama bekerja.

5. Gaji

Gaji adalah faktor dalam memenuhi kebutuhan hidup karyawan yang dianggap layak atau tidak.

Karyawan menghabiskan waktu rata-rata 40-50 jam seminggu di tempat kerja mereka sehingga lingkungan kerja memainkan peran penting dalam kehidupan organisasi. Hubungan antara fasilitas kerja dan kepuasan kerja juga menunjukkan bahwa karyawan yang merasa nyaman dengan lingkungan kerja mereka juga cenderung lebih puas dengan pekerjaan mereka. Ketika kompetisi tumbuh di sektor swasta meningkat dan lingkungan bisnis dinamis dan menuntut, telah menjadi penting bagi organisasi untuk mempertahankan fasilitas kerja yang sehat dan kondusif untuk mempertahankan produktivitas dan mencapai potensi maksimal mereka. Karyawan yang puas cenderung terinspirasi, efektif, dan juga berdedikasi pada pekerjaan mereka, yang pada gilirannya, meningkatkan efisiensi organisasi.

Fasilitas kerja adalah fasilitas yang disediakan oleh perusahaan untuk mendukung proses kerja dalam mencapai tujuan. Jenis-jenis fasilitas kerja adalah sebagai berikut (Mangkunegara, 2019):

1. Kondisi Kerja

Mendukung kondisi kerja dalam menyelesaikan tugas-tugas yang memadai sesuai dengan tugas-tugas yang harus diselesaikan. Sehingga kondisi kerja tidak hanya terbatas pada kondisi tempat kerja, seperti ventilasi, penerangan, keamanan dan lainnya.

2. Kelengkapan fasilitas kerja

Fasilitas, semua peralatan yang digunakan, digunakan, ditempati dan dinikmati oleh karyawan baik dalam kontak langsung dengan pekerjaan dan untuk kelancaran pekerjaan.

3. Lingkungan Kerja

Lingkungan kerja, merupakan faktor bagi karyawan untuk melakukan pekerjaannya secara optimal, jika karyawan menyukai lingkungan kerja tempat ia bekerja, maka 
karyawan akan merasa nyaman di tempat kerja.

Beberapa penelitian menunjukkan bahwa fasilitas kerja terkait erat dengan kepuasan kerja. Menurut Madusanka (2016), disimpulkan bahwa fasilitas kerja berkorelasi positif dengan tingkat tinggi karyawan pemimpin tim kepuasan kerja di Industri Pembuatan Ban Off Road (Madusanka \& Perera, 2016). Studi ini menjelaskan fasilitas kesejahteraan yang disediakan oleh perusahaan membantu meningkatkan standar hidup karyawan. Penelitian yang dilakukan di PT Sarana Argo Nusantara Medan menyatakan bahwa fasilitas kerja yang melibatkan kondisi kerja, tata letak, peralatan, ruang kerja, cahaya, ventilasi, perawatan kesehatan dan peralatan keselamatan memiliki pengaruh positif dan signifikan terhadap kepuasan kerja karyawan (Astuti \& Iverizkinawati, 2018).

Persentase keterlambatan karyawan unit rekam medis rumah sakit PGI Cikini adalah 15\% pada tahun 2018. Ini menunjukkan kurangnya disiplin dari karyawan yang menyebabkan ketidakpuasan di tempat kerja. Karyawan juga mengeluh tentang kurangnya fasilitas kerja yang disediakan oleh rumah sakit, sehingga menghambat proses kerja. Masalah ini adalah dasar dari penelitian ini untuk menganalisis korelasi antara fasilitas kerja dan kepuasan kerja karyawan unit rekam medis di Rumah Sakit PGI Cikini.

\section{METODE}

Penelitian ini adalah penelitian kuantitatif dengan desain penelitian cross sectional. Sampel dalam penelitian adalah 30 karyawan unit rekam medis di Rumah Sakit PGI CIkini. Penelitian dilakukan dari bulan Maret hingga Desember 2019.

Data dari penelitian ini adalah data primer yang diambil langsung dari lapangan dari hasil kuesioner yang dilakukan oleh responden. Instrumen yang digunakan dalam penelitian ini adalah kuesioner yang telah diuji validasi dan reliabilitasnya. Semua item pernyataan pada kuesioner berisi pilihan yang terdiri dari 4 kategori: sangat tidak setuju, tidak setuju, setuju, dan sangat setuju. Variabel penelitian ini adalah fasilitas kerja dan kepuasan kerja karyawan unit rekam medis di Rumah Sakit PGI CIKINI.

Data disajikan secara deskriptif untuk melihat karakteristik responden dan masingmasing variabel serta secara analitik untuk melihat korelasi antara fasilitas kerja dan kepuasan kerja menggunakan uji korelasi Pearson.

Indikator yang dinilai dalam kepuasan kerja adalah pekerjaan itu sendiri, pengawasan, rekan kerja, promosi, dan gaji. Sedangkan Indikator yang dinilai dalam fasilitas kerja adalah kondisi kerja, kelengkapan fasilitas kerja, dan lingkungan kerja.

Penelitian ini telah melewati kaji etik dan memperoleh Keterangan Lolos Kaji Etik (Ethical Approval) dengan Nomor 0330-19.385/DPKEKEP/FINAL.EA/UEU/VII/2019 oleh Dewan Penegakan Kode Etik Universitas Esa Unggul.

\section{HASIL}

Tabel 1. Distribusi Frekuensi Berdasarkan Karakteristik Responden

\begin{tabular}{lcc}
\hline \multicolumn{1}{c}{ Variabel } & f & $\mathbf{\%}$ \\
\hline Usia & & \\
$\leq 25$ tahun & 7 & 23,3 \\
$>25$ tahun & 23 & 76,7 \\
\hline Jenis Kelamin & & \\
$\quad$ Laki-laki & 10 & 33,3 \\
$\quad$ Perempuan & 20 & 66,7 \\
\hline Lama Kerja & & \\
$\quad<5$ tahun & 8 & 26,7 \\
$\quad \geq 5$ tahun & 22 & 73,3 \\
\hline Pendidikan Terakhir & & \\
$\quad$ Sekolah Menengah & & \\
Keatas/Kejuruan & 14 & 46,7 \\
$\quad$ Perguruan Tinggi & 16 & 53,3 \\
\hline
\end{tabular}

Dari total 30 responden, sebagian besar responden berusia>25 tahun adalah $76,7 \%$. Sebagian besar responden adalah perempuan dengan persentase $66,7 \%$. Sebagian besar responden memiliki lama kerja $>5$ tahun yaitu $73,3 \%$. Selanjutnya, untuk pendidikan terakhir, sebagian besar responden lulus dari perguruan tinggi dengan 53,3\%.

Indikator yang dinilai dalam kepuasan kerja adalah gaji, promosi jabatan, rekan kerja, pengawasan, dan pekerjaan itu sendiri. Pada indikator gaji pernyataan yang dinilai terkait ketepatan besaran gaji, kesesuaian gaji dengan standar pemerintah, penyediaan insentif selain gaji, dan kesesuaian insenti lain. Dari 30 responden, skor rata-rata jawaban responden terkait gaji yaitu 9,67 dengan standar deviasi 1,65 dan tingkat kepercayaan 95\% antara 9,05-10,28. Pada indikator promosi jabatan pernyataan yang dinilai adalah penghargaan sesuai kinerja, kebijakan promosi sudah tepat, dan pengembangan karyawan dilakukan berdasarkan kompetensi. Dari 30 responden, skor rata-rata jawaban responden terkait promosi jabatan yaitu 
7,37 dengan standar deviasi 1,43 dan tingkat kepercayaan 95\% antara 6,83-7,90. Pada indikator rekan kerja pernyataan yang dinilai adalah rekan kerja membantu pekerjaan, hubungan pekerjaan baik antar rekan kerja dan pimpinan, masing-masing karyawan tidak dibedakan dalam pengembangan. Dari 30 responden, skor rata-rata jawaban responden terkait rekan kerja yaitu 9,07 dengan standar deviasi 1,31 dan tingkat kepercayaan 95\% antara 8,58-9,56. Pada indikator pengawasan pernyataan yang dinilai adalah penyelia memberikan teguran jika salah, penyelia memberikan arahan, penyelia membantu menyelesaikan masalah, dan penilaian kerja dilakukan dengan objektif. Dari 30 responden, skor rata-rata jawaban responden terkait pengawasan yaitu 11,27 dengan standar deviasi 1,84 dan tingkat kepercayaan 95\% antara 10,58-11,95. Pada indikator pekerjaan itu sendiri pernyataan yang dinilai adalah kesempatan membuat keputusan, beban kerja berdasarkan kompetensi, bertanggung jawab terhadap pekerjaan, dan konflik dalam bekerja.Dari 30 responden, skor rata-rata jawaban responden terkait pekerjaan itu sendiri yaitu 11,10 dengan standar deviasi 1,84 dan tingkat kepercayaan 95\% antara 10,41-11,79. Secara keseluruhan dari total skor variabel kepuasan kerja didapatkan nilai rata-rata 48,47 dengan standar deviasi 6,50 dan tingkat kepercayaan 95\% antara 46,04-50,89.

Dari sebaran jawaban responden pada indikator pekerjaan itu sendiri responden setuju jika pekerjaan yang diberikan sesuai dengan kompetensi dan semua karyawan bertanggung jawab atas pekerjaan yang diberikan. Namun, ada $40 \%$ yang tidak setuju bahwa ketika karyawan bekerja diberi kesempatan untuk dapat membuat keputusan. Pada indikator pengawasan banyak responden setuju bahwa selama bekerja dilakukan pengawasan. Namun, ada responden yang menyatakan sangat tidak setuju jika penyelia memberikan teguran kepada karyawan yang salah $(6,7 \%)$ dan penilaian kinerja dilakukan dengan tepat (10\%). Pada indikator rekan kerja, banyak responden setuju bahwa saat bekerja rekan kerja dapat bekerja bersama. Namun, ada responden yang tidak setuju jika setiap karyawan diberi kesempatan yang sama untuk berkembang (20\%). Hal ini sejalan dengan responden yang menjawab tidak setuju sehubungan dengan promosi yang sesuai $(53,3 \%)$ pada indikator promosi. Pada indikator gaji, banyak responden menyatakan bahwa mereka tidak setuju jika gaji yang diberikan sesuai dengan standar dan ada insentif lain yang diberikan oleh rumah sakit untuk karyawan.

Tabel 2. Distribusi Jawaban Responden Terhadap Kepuasan Kerja Berdasarkan Indikator

\begin{tabular}{|c|c|c|c|c|c|c|}
\hline \multirow[t]{2}{*}{ Indikator } & \multirow[t]{2}{*}{ (Min-Max) } & \multirow[t]{2}{*}{ Mean } & \multirow[t]{2}{*}{ Median } & \multirow{2}{*}{$\begin{array}{c}\text { Std. } \\
\text { Deviasi }\end{array}$} & \multicolumn{2}{|c|}{$95 \% \mathrm{CI}$} \\
\hline & & & & & Lower & Upper \\
\hline Gaji & $7-13$ & 9,67 & 9,5 & 1,65 & 9,05 & 10,28 \\
\hline Promosi Jabatan & $5-10$ & 7,37 & 7,0 & 1,43 & 6,83 & 7,90 \\
\hline Rekan Kerja & $7-12$ & 9,07 & 9,0 & 1,31 & 8,58 & 9,56 \\
\hline Pengawasan & $6-14$ & 11,27 & 12,0 & 1,84 & 10,58 & 11,95 \\
\hline $\begin{array}{l}\text { Pekerjaan } \quad \text { Itu } \\
\text { Sendiri }\end{array}$ & $7-16$ & 11,10 & 12,0 & 1,84 & 10,41 & 11,79 \\
\hline Kepuasan Kerja & $32-58$ & 48,47 & 49,0 & 6,50 & 46,04 & 50,89 \\
\hline
\end{tabular}

Indikator yang dinilai dalam fasilitas kerja adalah kondisi kerja, kelengkapan fasilitas kerja, dan lingkungan kerja. Pada indikator kondisi kerja pernyataan yang dinilai adalah keamanan ruangan kerja, kondisi ruangan yang baik, kelembaban dan kebersihan ruangan yang baik, dan kondisi peralatan yang baik. Dari 30 responden, skor rata-rata jawaban responden terkait kondisi kerja yaitu 10,10 dengan standar deviasi 1,32 dan tingkat kepercayaan 95\% antara 9,61-10,59. Pada indikator kelengkapan fasilitas kerja, pernyataan yang dinilai adalah fasilitas kerja membantu dalam bekerja, peralatan membantu dalam bekerja, ketersediaan jaminan kesehatan, dan hak cuti karyawan. Dari 30 responden, skor rata-rata jawaban responden terkait kelengkapan fasilitas kerja yaitu 11,17 dengan standar deviasi 1,05 dan tingkat kepercayaan 95\% antara 10,77-11,56. Pada indikator lingkungan kerja, pernyataan yang dinilai adalah lingkungan terasa aman dan nyaman, tersedia kantin, tempat ibadah, dan parkir, ruangan kerja selalu tetap bersih dan terhindar dari kebisingan.Dari 30 responden, skor rata-rata jawaban responden terkait lingkungan kerja yaitu 7,97 dengan standar deviasi 1,45 dan tingkat kepercayaan 95\% antara 7,42-8,51. Secara keseluruhan dari total skor variabel fasilitas kerja didapatkan nilai rata-rata 29,23 dengan standar deviasi 2,59 dan tingkat kepercayaan 95\% antara 28,26-30,20.

Pada indikator kondisi kerja responden yang menyatakan tidak setuju dengan kondisi bangunan dalam kondisi baik (66,7\%). Ini didukung oleh responden yang tidak setuju dengan suhu, cahaya, dan sirkulasi udara yang 
memadai di kantor (50\%). Kondisi unit rekam medis saat ini di Rumah Sakit PGI CI tidak baik. Ruangan terlalu sempit dan ada barang-barang yang ditempatkan secara tidak teratur membuat karyawan merasa tidak nyaman. Pada indikator kelengkapan fasilitas kerja, responden merasa terbantu dengan peralatan yang ada. Namun, ada $43,3 \%$ responden yang tidak setuju tentang asuransi kesehatan yang diberikan. Sejalan dengan indikator kondisi kerja di mana banyak responden setuju bahwa perusahaan menyediakan peralatan, pada indikator lingkungan kerja banyak responden juga merasakan fasilitas seperti kantin dan tempat ibadah juga disediakan. Namun, sebanyak 43,3\% responden tidak setuju bahwa ruangan itu bersih dan bebas dari kebisingan.

Tabel 3. Distribusi Jawaban Responden terhadap Fasilitas Kerja Berdasarkan Indikator

\begin{tabular}{|c|c|c|c|c|c|c|}
\hline \multirow[t]{2}{*}{ Indikator } & \multirow[t]{2}{*}{ (Min-Max) } & \multirow[t]{2}{*}{ Mean } & \multirow[t]{2}{*}{ Median } & \multirow{2}{*}{$\begin{array}{c}\text { Std. } \\
\text { Deviasi }\end{array}$} & \multicolumn{2}{|c|}{$95 \% \mathrm{CI}$} \\
\hline & & & & & Lower & Upper \\
\hline Kondisi Kerja & $7-12$ & 10,10 & 10,0 & 1,32 & 9,61 & 10,59 \\
\hline $\begin{array}{l}\text { Kelengkapan } \\
\text { Fasilitas Kerja }\end{array}$ & $8-13$ & 11,17 & 11,0 & 1,05 & 10,77 & 11,56 \\
\hline Lingkungan Kerja & $5-12$ & 7,97 & 8,0 & 1,45 & 7,42 & 8,51 \\
\hline Fasilitas Kerja & $23-36$ & 29,23 & 30,0 & 2,59 & 28,26 & 30,20 \\
\hline
\end{tabular}

Pada uji korelasi akan terlihat tingkat korelasi antara fasilitas kerja dengan kepuasan kerja berdasarkan interpretasi pada Tabel 4 .

Tabel 4. Interpretasi Koefisien Korelasi

\begin{tabular}{cc}
\hline Koefisien Interval & Tingkatan Korelasi \\
\hline $0,00-0,199$ & Sangat rendah \\
\hline $0,20-0,399$ & Rendah \\
\hline $0,40-0,599$ & Sedang \\
\hline $0,60-0,799$ & Kuat \\
\hline $0,80-1,000$ & Sangat Kuat \\
\hline
\end{tabular}

Berdasarkan tabel 5 fasilitas kerja dan kepuasan kerja memiliki hubungan linier yang signifikan secara statistik (p-value 0,000). Korelasi pearsondigunakan untuk menentukan hubungan antara fasilitas kerja dan kepuasan kerja. Ada korelasi positif yang kuat antara fasilitas kerja dan kepuasan kerja $\left(\mathrm{r}_{\mathrm{xy}}=0,609\right)$. Hasil penelitian juga menunjukkan $\mathrm{r}^{2}$ adalah $0,370(37,0 \%) \cdot r^{2}$ menunjukkan bahwa persentase hubungan antara variabel independen (fasilitas kerja) dan variabel dependen (kepuasan kerja) adalah $37,0 \%$.

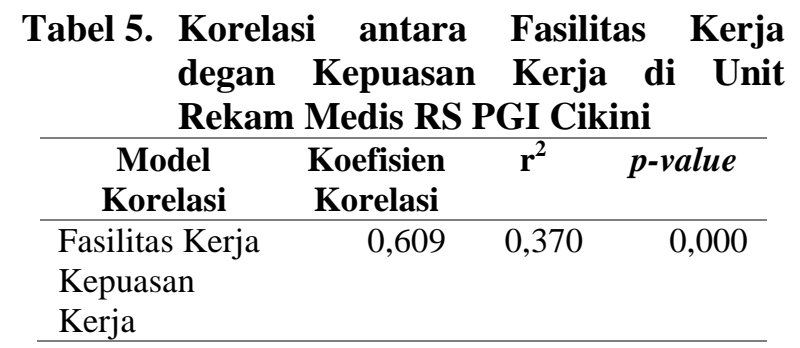

\section{PEMBAHASAN}

Pada hasil penelitian dijelaskan sebelumnya bahwa terdapat responden yang menyatakan tidak dapat membuat keputusan saat bekerja. Dalam suatu organisasi keterlibatan kerja karyawan sangat besar. Ada beberapa teori dari berbagai sumber yang dapat menjelaskan definisi dari keterlibatan kerja yaitu sejauh mana seseorang mengidentifikasi secara psikologis dengan pekerjaannya dan pentingnya pekerjaan bagi citra diri seseorang. Dengan melibatkan karyawan misalnya dalam mengambil keputusan akan membuat mereka lebih termotivasi, lebih berkomitmen pada organisasi atau perusahaan, lebih produktif, dan lebih puas dengan pekerjaan mereka (Hardian, 2017). Selanjutnya responden juga merasa penyelia tidak menegur karyawan yang lalai. Pengawasan dilakukan untuk mengetahui sedini mungkin kesalahan dan sekaligus melakukan perbaikan sebelum membawa dampak yang lebih besar. Selain itu, fungsi pengawasan untuk mencegah kesalahan terjadi dan untuk memperkuat rasa tanggung jawab karyawan. Dua poin yang merupakan sistem pemantauan keberadaan rencana tertentu dengan memberikan instruksi dan wewenang kepada bawahan. Jika kedua hal ini tidak berhasil, maka pengawasan tidak dapat bekerja secara efektif (Putra, 2015).

Pada hasil penelitian juga terdapat pula responden yang menyatakan promosi jabatan belum sesuai pelaksanaannya. Dengan promosi jabatan memungkinkan bagi karyawan untuk meningkatkan kinerja mereka karena untuk mencapai persyaratan yang diperlukan. Jika tidak ada promosi posisi, memungkinkan karyawan untuk bekerja seperti biasa tanpa prestasi tertentu (Damayanti, Silviana; Harini, 2018). Pada pernyataan terkait gaji dan insentif dirasa pula oleh responden belum optimal. Seseorang yang bekerja mengharapkan imbalan atau gaji yang 
diterima sesuai dengan jenis pekerjaannya, maka ada juga rasa kegembiraan yang semakin baik. Imbalan kerja ada banyak bentuk, tidak selalu dalam bentuk uang, imbalan adalah hal-hal yang mendorong kerja keras (Yuda Putra, Kurnia Dwi; Wahyuni, Ida, Kurniawan, 2018).Kepuasan terhadap gaji terdiri dari beberapa elemen, elemen yang paling jelas adalah jumlah gaji yang diterima oleh karyawan. Secara umum, motivasi orang untuk bekerja adalah untuk dapat memperoleh kepuasan dalam bentuk uang, karena uang dapat digunakan untuk memenuhi semua jenis kebutuhan (Gunawan \& Kusniawati, 2019).

Dalam suatu perusahaan untuk mencapai suatu tujuan diperlukan peralatan pendukung yang digunakan dalam proses atau kegiatan di perusahaan. Fasilitas yang digunakan oleh masing-masing perusahaan adalah berbagai bentuk, jenis dan manfaat. Semakin besar kegiatan suatu perusahaan, semakin lengkap fasilitas dan fasilitas pendukung dalam proses kegiatan untuk mencapai tujuan tersebut. Di ruang rekam medis RS PGI Cikini ada komputer, ruang penyimpanan, dan alat pendukung lainnya.

Pada hasil penelitian responden menyatakan jaminan kesehatan yang disediakan belum optimal pelaksanaanya. Penyediaan jaminan kesehatan terkait erat dengan penciptaan program perawatan kesehatan karyawan, dan juga karena ada peraturan pemerintah yang mengatur masalah keselamatan dan kesehatan karyawan dalam melaksanakan pekerjaan mereka (Dahlius, Apri, Ibrahim, 2016). Kebijakan jaminan kesehatan kepada karyawan telah dilakukan oleh manajemen RS PGI Cikini. Sebelum adanya BPJS Kesehatan, karyawan dapat melakukan pengobatan di rumah sakit secara langsung, tetapi sekarang setiap karyawan harus mengikuti peraturan BPJS Kesehatan di mana rumah sakit sekarang menjadi rujukan setelah melalui fasilitas kesehatan primer. Inilah yang membuat jaminan kesehatan menurut karyawan mengalami pembatasan.

\section{DAFTAR PUSTAKA}

Astuti, R., \& Iverizkinawati, I. (2018). Pengaruh Kepemimpinan dan Lingkungan Kerja terhadap Kepuasan Kerja Karyawan pada PT. Sarana Agro Nusantara Medan. Jurnal Ilman, 6(1), 26-41.

Dahlius, Apri, Ibrahim, M. (2016). Pengaruh Fasilitas Kerja Terhadap Kepuasan Kerja Karyawan Pada Pt. Bank Riau KepRi Cabang Teluk Kuantan Kabupaten
Pada penelitian ini terdapat korelasi yang positif antara fasilitas kerja dengan kepuasan kerja. Penelitian ini sejalan dengan penelitian yang dilakukan di PT Dirgantara Indonesia yang menyatakan ada pengaruh antara fasilitas kerja dan kepuasan kerja karyawan, semakin tinggi atau lebih baik kualitas fasilitas kerja akan meningkatkan kepuasan kerja karyawan, dan jika fasilitas kerja menurun itu akan berdampak pada penurunan kepuasan kerja karyawan. 30,7\% dari kepuasan kerja dapat dijelaskan oleh keadaan fasilitas kerja (Pangarso, Fajar Firdaus, \& K. Moeliono, 2016). Penelitian di PT. Bank Riau Kepri Cabang Teluk Kuantan menunjukkan hasil yang serupa bahwa fasilitas kerja mempengaruhi kepuasan kerja. Dari hasil penelitian ini ditemukan bahwa fasilitas kerja memiliki efek 95\% untuk menciptakan kepuasan kerja (Dahlius, Apri, Ibrahim, 2016).

\section{SIMPULAN}

Kepuasan kerja karyawan di unit rekam medis RS PGI Cikini umumnya baik. Namun, beberapa hal yang perlu diperhatikan adalah keterlibatan karyawan dalam pengambilan keputusan, peluang untuk mendapatkan promosi, dan standar gaji yang diberikan kepada karyawan. Keseluruhan fasilitas kerja di unit rekam medis Rumah Sakit PGI Cikini menurut responden dalam kondisi baik. Namun, beberapa hal yang perlu diperhatikan adalah kondisi ruang kerja, pencahayaan spasial, suhu, sirkulasi udara, dan kebisingan. Hal lain yang perlu diperhatikan adalah pemenuhan asuransi kesehatan, dan juga kebersihan ruangan. Fasilitas kerja dan kepuasan kerja memiliki signifikan secara statistik ( $p$-value 0,000). Dari hasil penelitian ini ditemukan bahwa fasilitas kerja memiliki pengaruh $37 \%$ untuk menciptakan kepuasan kerja. ini menunjukkan ada faktor lain yang mempengaruhi kepuasan kerja.

Kuantan Singingi. JOM FISIP, 3(2), 123130.

Damayanti, Silviana, Harini, S. (2018). Pengaruh Promosi Jabatan Dan Kompensasi Terhadap Kepuasan Kerja Karyawan Pada PT Perwita Margasakti Jakarta. Jurnal Vistionida, $\quad$ 4, 20. http://jurnal.upgriplk.ac.id/index.php/moral ity/article/view/63/49 
Gunawan, A., \& Kusniawati, A. (2019). Analisis Faktor-Faktor Yang Menentukan Kepuasan Kerja Pegawai Puskesmas. Journal of Management Volume 3 Number 2 Page (307-319), 3(2).

Hardian, A. (2017). Menyoal Kembali Keterlibatan Pengambilan Keputusan dan Motivasi Berprestasi Terhadap Kepuasan Kerja. Komunikasi, VIII (September), 281292.

Kusumah, M. (2016). Pengaruh kompensasi kepemimpinan terhadap kepuasan karyawan dan implikasinya terhadap kinerja karyawan (Studi Terhadap Karyawan Penunjang Medis Rumah Sakit Al Islam Bandung). [Tesis]. Bandung: Universitas Pasundan.

Luthans, F. (2011). Perilaku Organisasi (Edisi Baha). Yogyakarta: ANDI.

Madusanka, W., \& Perera, G. D. (2016). The Impact of Welfare Facilities on Job Satisfaction among Team Leaders in Off Road Tyre Manufacturing Industry. Proceedings of International $H R$ Conference, 3(1), 148-156. Retrieved from http://journals.sjp.ac.lk/index.php/phrc/arti cle/view/2911

Mangkunegara, A. (2019). Evaluasi Kinerja SDM. Bandung: PT Refika Aditama.

Pangarso, A., Fajar Firdaus, F., \& K. Moeliono, N. (2016). Pengaruh Fasilitas Kerja Terhadap Kepuaasan Kerja Karyawan Divisi Sumber Daya Manusia dan Diklat PT. Dirgantara Indonesia. Jurnal
Administrasi Bisnis, 12, 50-62.

Prayoga, D., Lailiyah, S., \& Eka Sari, J. D. (2017). Analisis Kepuasan Karyawan Dan Akreditasi Rumah Sakit Umum Daerah Blambangan Kabupaten Banyuwangi. Jurnal Riset Akuntansi Dan Bisnis Airlangga, 2(2), 269-289. https://doi.org/10.31093/jraba.v2i2.45

Putra, E. (2015). Peranan Pengawasan Dalam Meningkatkan Efektivitas Kerja Karyawan Pada Pt.Kereta Api (Persero) Divisi Regional Iii Sumatera Selatan. Jurnal Media Wahana Ekonomika, 12(1), 54-67.

Soetrisno, E. (2017). Manajemen Sumber Daya Manusia. Kencana.

Sulistyarini, N. (2013). Faktor-faktor yang berhubungan dengan kepuasan kerja pegawai tetap DI Rumah Sakit Haji Jakarta Tahun 2013. [Skripsi]. Jakarta: Universitas Islam Negeri Jakarta. https://doi.org/10.11113/jt.v56.60

Thakur, D. M. B. (2020). Exploring the relationship between Work Environment and Job Satisfaction. Our Heritage, 10(AUTUMN), 49-50. https://doi.org/10.1259/0007-1285-11-121-38

Yuda Putra, Kurnia Dwi; Wahyuni, Ida, Kurniawan, B. (2018). Hubungan Supervisi, Rekan Kerja, Gaji, Keamanan Kerja, Kondisi Kerja, Promosi Jabatan Dan Jenis Pekerjaan Dengan Kepuasan Kerja. Jurnal Kesemahatan Masyarakat, 6(4), 321-329.

http://ejournal3.undip.ac.id/index.php/jkm 